\title{
Social Background and Elite Composition: Jewish Political Elite During the British Mandate
}

\author{
Taysir Nashif \\ United Nations, New York
}

\begin{abstract}
This article, which utilizes the quantitative social-background approach, sets as its objective to empirically discern correlations between the behavior of the Jewish political elite, embodied in the Jewish Agency for Palestine in the period from 1921 to 1948, and the following social-background variables: age, foreign travel, occupation as a path to political power, regional affiliation, ideology, and political opportunity, of the JAE membership. Diversity of the social-background variables and, particularly, the multitude of languages they knew, explain, to a considerable extent, firstly, the wide variety of their social, political and economic views, and, secondly, the elite's resort to direct contact with Western governments and peoples in communicating and promoting their political ideology, thus facilitating the realization of the Zionist project.
\end{abstract}

Keywords: elite communication, circulation, Jewish elite, mandate over Palestine, politics, regional affiliation, Zionism

\section{Historical Background}

As a political movement, Zionism was launched in the 1880s by Jewish European intellectuals. These individuals and their successors were successful in providing the Zionist movement with effective leadership and organization (Khouri, 1971, p. 3). The World Zionist Organization (WZO), in particular, emerged as an important and powerful international body (Cohen, 1950, p. 312). To establish the Jewish national home, Zionist leaders envisaged the promotion of Jewish immigration to, and settlement in, Palestine, the unification of world Jews, the fostering of Jewish national consciousness and the taking of steps to secure various governments' support for the Zionist goals (Patai, 1971, p. 114).

The Allied forces completed the occupation of Palestine in 1918. On 25 April 1920, the Allied Supreme Council of the Peace Conference in San Remo assigned to Great Britain the mandate over Palestine, which incorporated the Balfour Declaration, promising British support for the establishment of a Jewish national home in Palestine. Article 4 of the mandate provided for the recognition of a Jewish agency for Palestine to co-operate with the mandatory power in creating a Jewish national home. It also provided that "the Zionist Organization ... shall be recognized as such agency” (Patai, 1971, pp. 757-758). The Arab population of Palestine, both Muslim and Christian, amounted in 1918 to 644,000 persons, whereas the Jews numbered about 56,000 .

Taysir Nashif, B.A. in Arabic Language and Literature, Hebrew University; M.A. in Middle Eastern Studies, University of Toronto; Ph.D. in Political Science, State University of New York at Binghamton. He served as a Professor of sociology at the University of Oran, Algeria, and taught Arabic at Temple University, PA. Dr. Nashif has been a member in several professional associations, including Middle East Studies Association and Association of Third World Studies. 
Organizationally, the highest organ of the World Zionist Organization was the biennial Congress. It decided on general Zionist policy and elected the General Council (Actions Committee), the Executive, and the president. The Executive was charged with implementing the Zionist policy adopted by the Congress and the General Council. In 1929, the Jewish Agency was expanded to include not only the Zionists, as was the case until then, but also the non-Zionist Jews with a view to enlisting the financial support of the wealthy non-Zionist Jews in the United States and other countries.

However, for a variety of reasons-including political disagreements between the Zionist and non-Zionist members of the Jewish Agency Executive (JAE), and the considerable destruction of the European Jewry (1939-1945) - the principle of parity of representation on which the enlarged Jewish Agency rested was not adhered to. In fact, the Zionist component became predominant.

The British ruled Palestine from 1917 until 1948. The main actors in the Palestine environment during this period were the British Government, the World Zionist Organization, the Jewish community in Palestine (Yishuv), and the Arabs of Palestine. The Yishuv enjoyed the status of a partially autonomous entity, a state-in-the-making. Its main governing bodies comprised the Vaad Leumi (the National Council of Palestine Jews) and the Executive Committee of the Zionist organization, which was called the Jewish Agency for Palestine. The British Mandatory authorities entrusted to these institutions certain functions of self-government (Lenczowski, 1975, p. 164).

In 1947, the United Nations Special Committee recommended a partition of Palestine into a Jewish state, an Arab state, and an international zone of Jerusalem. Keen to keep the country undivided, the majority of the Palestine Arabs rejected the partition plan. On 14 May 1948 Israel's independence was proclaimed by the Jewish National Council, representing the Jewish community in Palestine and the Zionist movement. This independence took effect concurrently with the termination of the British Palestine Mandate on the following day. The Jewish National Council declared that it would act as a Provisional Council of State until elected permanent authorities were established under a constitution. The Provisional Council of State designated the JAE, headed by David Ben-Gurion, as the Provisional Government of the state.

\section{Identification of the Political Elite}

In identifying the Jewish political elite, the article employs the institutional approach. The JAE members are considered the Jewish political elite of the world Zionist movement. The JAE is of a special interest because it was the main forum for Zionist politics and the main arena in which its members acted and interacted. This article covers nearly twenty-seven years, beginning with 1921, year in which the Executive of the WZO was elected by the 12th Zionist Congress and a year after the San Remo Conference decided to grant the mandate under the League of Nations to Great Britain. The study ends with the termination of the British mandate and the establishment of the State of Israel in May 1948. Twelve Jewish Agency Executives, numbering 64 individuals, were elected between 1921 and 1948.

\section{Age}

All the members of the Jewish Agency Executive (JAE) got politically involved in early life, well before taking up their first political office. In many cases, their political involvement came during boyhood and early student life. As Table 1 indicates, the average age of the JAE members at the beginning of first political office stood at 31 years, which is, in absolute and relative terms, young. This average age would have been lower 
were it not for the inclusion in the JAE of 12 members who, when assuming their first political office, were in their 40s and 50s. Moreover, the youth of the JAE members at the first political office kept their average age at first membership in the JAE relatively young — 45.9 years.

Table 1

Age of JAE Members: Aggregate Count

\begin{tabular}{ll}
\hline & Years \\
\hline Average age of the Jewish elite members at time of first political office & 31.0 \\
Average age of the Jewish elite members at first JAE membership & 45.9 \\
\hline
\end{tabular}

As set forth, the JAE is the subject of study as of September 1921, the year in which the 12th Zionist Congress was convened in Karlovy Vary (Carlsbad). It should be noted that two members of the JAE were elected by Zionis Congresses that preceded the 12th Zionist Congress. One of them, Menahem Ussishkin, was elected to the Zionist Executive at the 7th Congress in 1905, while the other, Nahum Sokolow, was elected to the Zionist Executive at the 10th Congress in 1911. In calculating the average age of the Jewish elite group at the first JAE membership, those two dates were taken into account.

Analysis over time of the average age data of the JAE shows a significantly high rate of circulation of the Jewish political elite. As Table 2 shows, though tending to be on the higher side, the average age of each of the JAEs was not that high. It shows that each JAE comprised both young and middle-aged members. The average age of the members grew from 46.4 years for the 1921 JAE to 52.6 years for the 1946 JAE. The average age of the JAE was characterized by marked fluctuations. In terms of general trend, there was an unmistakable, though slow, rise in average age. The age of the $1921 \mathrm{JAE}$ averaged 46.4 years. The average age rose uninterruptedly in subsequent years, reaching a high of 50.8 years for the 1929 JAE. After this high, a decline set in in average age, reaching an all-time low of 45.2 years for the 1931 JAE. Comparatively young non-Zionist recruits to the 1931 JAE account for the lower average age of the Jewish elite. After an all-time high of 54 years for the 1935 JAE, the average age of the 1946 one stood at 52.6 years. There was a difference of over six years between the first $1921 \mathrm{JAE}$ and the last one of 1946.

Table 2

Average Age of the Jewish Elite by Each JAE

\begin{tabular}{lll}
\hline JAE & No. & $\begin{array}{l}\text { Average age } \\
\text { (in years) }\end{array}$ \\
\hline September 1921 & 15 & 46.4 \\
August 1923 & 13 & 46.4 \\
August 1925 & 15 & 49.9 \\
August-September 1927 & 9 & 51.0 \\
July-August 1929 & 13 & 50.8 \\
October 1930 & 10 & 49.7 \\
July 1931 & 12 & 45.2 \\
September 1933 & 13 & 49.6 \\
August-September 1935 & 15 & 54.0 \\
August 1937 & 20 & 51.0 \\
August 1939 & 26 & 51.4 \\
December 1946 & 21 & 52.6 \\
\hline
\end{tabular}


Unquestionably, the over-six-year rise was a product of the aging of the older recruits, and it would have been at a faster rate had it not been for the admission of new younger recruits to the political elite group. Considering the length of 25 years of service on the JAE, this rise in average age could not be viewed as considerable, and it gives validity to the argument that there was an infusion of fresh younger blood into the elite group and a narrower generation gap between the Jewish elite and the masses. In the course of the 25-year period, between 1921 and 1946, new younger recruit to the elite group kept the average age rise at a slower pace. This lower average age points at the fact that bureaucracy was negligible in hindering political mobility to reach elite status. It is a pattern of elite-age structure probably reflecting an elite group's action-oriented tendency.

A revealing method for the ascertainment of the circulation of the Jewish elite is to find out if there were changes in the average age of the old and new recruits to the 12 JAEs, and, should there have been changes, to discover their direction. Those members who were fresh recruits to the JAE are regarded as new recruits. After serving on a JAE for the first time, they are considered as old recruits, even though their election to following JAEs was intermittent.

As Table 3 shows, there was a marked discrepancy in average age between the older carry-over recruits and the younger new recruits in the overwhelming majority of the JAEs, with the new recruits younger than the carry-over recruits. Only in the $1925 \mathrm{JAE}$ was the average age of the newcomers higher by a little over than one year than that of the former-recruits category. The average-age difference in average age is an indication of the injection of younger blood into the elite group. It may be an indication of the youth's daring to be involved in the Zionist activity, showing their strong motivation to promote the Zionist project, and showing an expedited process of younger members assuming elite status.

Table 3

Average Age and Percentage of Old and New JAE Members by Each JAE

\begin{tabular}{llllllll}
\hline JAE & No. & \multicolumn{3}{c}{ Old recruits } & \multicolumn{3}{c}{ New recruits } \\
\hline & & No. & $\%$ & Average age & No. & $\%$ & Average age \\
\hline $9 / 1921$ & 15 & & & 15 & 3 & 100.0 & 46.4 \\
$8 / 1923$ & 13 & 10 & 76.9 & 48.5 & 23.1 & 39.7 \\
$8 / 1925$ & 15 & 13 & 86.7 & 49.8 & 2 & 13.3 & 51.0 \\
$8-9 / 1927$ & 9 & 6 & 66.7 & 52.0 & 3 & 33.3 & 50.7 \\
$7-8 / 1929$ & 13 & 10 & 76.9 & 51.6 & 3 & 23.1 & 47.0 \\
$10 / 1930$ & 10 & 6 & 60.0 & 52.5 & 4 & 40.0 & 45.5 \\
$7 / 1931$ & 12 & 5 & 41.7 & 49.0 & 7 & 58.3 & 42.4 \\
$9 / 1933$ & 13 & 8 & 61.5 & 49.9 & 5 & 38.5 & 49.2 \\
$8-9 / 1935$ & 15 & 11 & 73.3 & 54.8 & 4 & 26.7 & 51.0 \\
$8 / 1937$ & 20 & 15 & 75.0 & 53.7 & 5 & 25.0 & 43.6 \\
$8 / 1939$ & 26 & 20 & 76.9 & 52.7 & 6 & 23.1 & 47.3 \\
$12 / 1946$ & 21 & 14 & 66.7 & 54.9 & 7 & 33.3 & 42.0 \\
\hline
\end{tabular}

The quantity of new entrants to the JAE is an index of the extent of the circulation of the political elite. Throughout the period covered there had been a continuing infusion of new members into the Jewish elite. In terms of the number of new entrants, the JAEs may be divided into two categories. The first category includes those JAEs serving between 1923 and 1929. The number of new entrants to each of these JAEs was usually three. The second category comprises the JAEs functioning between 1930 and 1946. A larger number, 
fluctuating between four and seven, of new entrants were admitted to these JAEs. The increasingly larger numbers of individuals serving on the JAE for the first time may be indicative of the Jewish elite's increased openness to wider Jewish communities.

With the exception of the $1925 \mathrm{JAE}$, whose new entrants contingent made up 13.3 percent of the JAE membership, the percentage of the new entrants in each JAE ranged between a low of 23.1 and a high of 58.3. Given the relatively short two-year span between the elections of the JAEs, these percentages of fresh recruits to the political elite are considerable. They reflect a pattern of active elite circulation. Given the definition adopted here of new and old recruits, and given the relatively short time distance between JAEs, the JAE member's service as a new entrant did not last for long. No sooner did a person enter the JAE as a new member than he/she served on subsequent JAEs as an old recruit. Had another criterion was adopted for categorizing "new entrants" and "old entrants" and had the time distance between one JAE and the other been longer, the percentage of the new entrants in the JAE composition would have been higher and the average age discrepancy between new and old recruits would have been wider.

The lack of increase of the average age of the JAE, in spite of the passage of time, indicates the continued strong participation of the youth in the political organizations.

The higher average age of the carry-over members than that of the new members is consistent with the nature of political action, where it takes a longer time before people engaging in political activity reach elite status.

Inasmuch as the size and age of the group of new entrants to the political elite status are an index of generational continuity, the sizable percentage of the new younger recruits in the Jewish elite suggests that a narrower gap existed between the Jewish elite and communities. This contingent served as an agency of continuous change for the transmission of political and cultural messages from the bottom to the top.

The way the categories of new and old members in the JAE were defined is an important factor in explaining the rising average age of older recruits. According to the method of categorizing old and new recruits, once a member has entered the JAE, unless such membership is discontinued through attrition, he/she would in most cases continue serving on the JAE as old recruits in succeeding JAEs.

As indicated in Table 4, the average age of the Zionist members was higher than that of the non-Zionist members of the JAE. Non-Zionist members were elected to membership in the JAE mainly because of their wealth and the prospect they held for financial contribution to the realization of the Zionist project. This financial consideration was a major factor for the fact that these members' political road to serving on the JAE was shorter by 3.5 years than that for the non-Zionist members.

Table 4

Average Age of the Jewish Elite at First JAE Membership by Ideological Identification: Aggregate Count

\begin{tabular}{llll}
\hline Ideological identification & No. & Percentage & Average age (in years) \\
\hline Zionists & 57 & 89 & 46.7 \\
Non-Zionists & 7 & 11 & 43.2 \\
Total & 64 & 100 & \\
\hline
\end{tabular}

\section{Foreign Travel}

The Jewish political elite had frequent and extensive direct contact with many Western countries. Actually, no elite group member stayed in one country only. Table 5 breaks down the Jewish elite by the number of 
countries visited or stayed in as late as May 1948. This number is not exhaustive of the countries visited or stayed in. In quite a few cases it was not possible to know how many countries JAE members stayed in, and to identify the countries visited. In a number of cases, the author came across statements such as "he went to Europe", "he was on numerous missions to Europe and North America on behalf of the Jewish Agency"- -statements that obviously do not help precisely know the identity of the countries covered by such trips.

Table 5

A Breakdown of the Jewish Elite by the Number of Countries Visited or Stayed-in Until May 1948

\begin{tabular}{lll}
\hline No. of countries & JAE members & Percentage \\
\hline Two to five & 21 & 32.8 \\
Six to nine & 28 & 43.7 \\
Ten to thirteen & 14 & 21.9 \\
Thirty-five & 1 & 1.6 \\
Total & 64 & 100.0 \\
\hline
\end{tabular}

There were various reasons for the Jewish elite's foreign travel. These reasons were not mutually exclusive. A portion of the elite group travelled for study or visit purposes. A part of them immigrated to other countries, including Palestine and the United States. Some members travelled in order to attend non-political international conferences, such as the International Municipalities Conference convened in Paris. A few members proceeded to other countries for business interests. In a relatively few cases, members visited foreign countries in a political, economic and diplomatic capacity as officials of the governments of their respective countries. In many cases, members travelled abroad as delegates to international political conventions. By virtue of their political, economic and diplomatic positions in the World Zionist Organization (WZO) and the Jewish Agency for Palestine, all JAE members proceeded on numerous missions abroad.

Table 6 shows the twelve countries most visited or stayed in by JAE members and the number of members staying in each of these countries. The countries of birth are included in the count.

Table 6

Twelve Most Visited or Stayed-in Countries by the Jewish Elite Group

\begin{tabular}{lll}
\hline Country & No. of members & Percentage in the elite group \\
\hline Palestine & 59 & 92.2 \\
Switzerland & 46 & 71.9 \\
Russia & 43 & 67.2 \\
Britain & 42 & 65.6 \\
Austria & 37 & 57.8 \\
Czechoslovakia & 37 & 57.8 \\
Germany & 36 & 56.2 \\
USA & 35 & 54.7 \\
Holland & 24 & 37.5 \\
Poland & 19 & 29.7 \\
France & 17 & 26.6 \\
Turkey & 7 & 10.9 \\
\hline
\end{tabular}

The JAE members stayed in at least as many as 42 countries. This diversity of countries reflect the geographical distribution of the Jewish organizations, both Zionist and non-Zionist, over the world, particularly 
in the West, through whose framework the JAE members acted. This distribution is an index of the intensity and comprehensiveness of the Zionist political activity. As a matter of course, this leadership, through its frequent travel and residence in other countries, had acquired various European and American customs and ways of thinking and behaving, and gained rich political experiences. The elite members familiarized themselves with the then prevailing political and ideological trends on the Western scenes. On the basis of an immediate contact with political and prominent social personages and of knowledge of the psycho-political attitudes of the Western peoples, the Jewish elite were in a better position to build a suitable strategy of policy and of policy execution. The Jewish elite were able to translate social and political experiences in the Western countries into bases on which Zionist national policies were formulated.

The Jewish elite had very little contact with the Arab neighbors surrounding Palestine, even though over half of the JAE members were domiciles in this land, and in spite of the fact that the great majority of the population was Arab. Egypt, Lebanon, Syria and Jordan were visited by one JAE member each. The two Arab countries of Iraq and Tunisia, which have no common borders with Palestine, were visited by one member each. Meagerness of contacts on the part of the JAE members and the Arab political elite is attributable to political disagreement regarding the future of Palestine.

The Jewish elite had a little personal contact with peoples in other parts of the world. It is quite obvious that the Jewish elite saw the West as the political and economic center of the world and that only through Western political, moral, economic and diplomatic backing could the Zionist aim of establishing a Jewish state in Palestine be realized. Hence, the Jewish elite concentrated efforts to perpetuate Western backing of the Zionist aspiration South-West Asia. This, of course, should not be construed as lessening the importance of the related factors that led to the concentration of the Zionist political activity in the West, namely, the Jewish demographic concentration and the birth of the elite members in the West. These two factors, and the preponderant political weight of the West during the study period offered a natural basis for very close political ties with the US and Europe.

\section{Occupation as a Path to Political Power}

The largest group of original occupations of members of the Jewish Agency Executive (JAE) was in bureaucracy, numbering 16 members, representing a quarter of the entire elite group (see Table 7). This percentage attests to the importance of bureaucracy as a stepping stone to political prominence, and reflects a heavy reliance of the Jewish elite group on bureaucrats. Through their long period of service in the bureaucratic field, these members gained experience needed to manage organizational needs.

Table 7

Original Occupational Sources of Recruitment of the Jewish Political Elite Group: Aggregate Count

\begin{tabular}{lll}
\hline Occupation & No. & Percentage \\
\hline Bureaucracy & 16 & 25.0 \\
Law & 14 & 21.9 \\
Rabbinical function & 6 & 9.4 \\
Finance & 6 & 9.4 \\
Engineering & 5 & 7.8 \\
Journalism & 5 & 7.8 \\
Academia & 4 & 6.2 \\
Teaching (non-college level) & 3 & 4.7 \\
\hline
\end{tabular}


(table 7 continued)

\begin{tabular}{lll}
\hline Occupation & No. & Percentage \\
\hline Medicine & 2 & 3.1 \\
Librarianship & 1 & 1.6 \\
Military & 1 & 1.6 \\
Information unavailable & 1 & 1.6 \\
Total & 64 & 100.0 \\
\hline
\end{tabular}

The second largest occupational source of elite recruitment was law, numbering 14 persons, and making up 21.9 percent of the elite group. Data are unavailable on the percentage of the law-educated in the university-educated group of the Jewish communities. However, one is inclined to have the view that the existence of a contingent with education of law representing nearly 22 percent of the elite group is probably indicative of the overrepresentation of the legal profession at the expense of other occupations and the considerable influence exerted by generalists within the Jewish political elite.

The rabbinical functionaries were the third largest group, numbering six and making up 9.4 percent of the elite group. Obviously, Jewish religious studies were their field of learning. The election of six rabbis to the JAE probably was a reflection of the influence exerted by Jewish religious clerics in determining the policy orientation of the world Zionist movement.

Finance was the original occupation for six individuals, forming 9.4 percent of the elite group, and engineering for five, making up 7.8 percent. The combined 17.2 percent of both groups point at the Jewish elite's considerable reliance on specialists and at their interest in technical and financial activity.

College and non-college teaching was the original occupation for seven members of the elite group. Traditionally, academia enjoyed a considerable prestige. Maybe, Chaim Weizmann's lectureship in biological science at the university level played an important role in his political prominence.

Journalism was the original occupation for five elite members; medicine, for two; and librarianship and military, for one JAE member each.

\section{Regional Affiliation}

One striking feature of the Jewish elite group is the fact that its overwhelming majority was born in Europe and North America: sixty-two members, making up 96.9 percent of the total membership. As to the remaining two, whereas the birth-place of a member was not known, the birth-place of the other was India. He was born to a British Jewish family whose head was in the British Foreign Service. Thus, he is regarded as a Briton in origin. The West, Tzarist Russia, the United States and Poland, was the area where the largest Jewish population concentrations existed. As Table 8 indicates, the Jewish population in Europe and North America made up almost 90 percent of world Jewry.

Table 8

A Breakdown of World Jewry by Areas (in 1939)*

\begin{tabular}{ll}
\hline Area & Percentage \\
\hline European and North American countries & 86.6 \\
Countries other than European and North American & 9.2 \\
Countries from both area groups & 4.2 \\
Total & 100.0 \\
\hline
\end{tabular}

Note. ${ }^{*}$ Udin, p. 77. 
Comparing the proportion of Western Jews in the JAE with that of the Western Jews in the total world Jewish population, it becomes clear that the Western Jews on the JAE were overrepresented. This overrepresentation is explicable by a number of factors. Zionism as a political movement originated in Europe. Western Jews were the forerunners, organizers and promoters of political Zionism. Western Jews reached the stage of Jewish national consciousness much earlier than did the Jews living in Asian and African lands. The social, political and economic hardships attending Jewish life in some parts of Europe served as a stimulus for a considerable Jewish espousal of Zionism.

Table 9

A Breakdown of the Jewish Elite by Country of Birth

\begin{tabular}{|c|c|c|c|c|}
\hline Country of birth & No. & Percentage & No. & Percentage \\
\hline Tsarist Russia & & & 21 & 32.8 \\
\hline Byelorussia* & 9 & 14.0 & & \\
\hline Ukraine & 9 & 14.0 & & \\
\hline Russia & 3 & 4.7 & & \\
\hline Poland & & & 12 & 18.7 \\
\hline Germany & & & 6 & 9.4 \\
\hline USA & & & 6 & 9.4 \\
\hline New York State & 4 & 6.2 & & \\
\hline Maryland & 1 & 1.6 & & \\
\hline Ohio & 1 & 1.6 & & \\
\hline Rumania & & & 5 & 7.8 \\
\hline Britain & & & 3 & 4.7 \\
\hline Lithuania & & & 2 & 3.1 \\
\hline Austria & & & 1 & 1.6 \\
\hline Canada & & & 1 & 1.6 \\
\hline Czechoslovakia & & & 1 & 1.6 \\
\hline Hungary & & & 1 & 1.6 \\
\hline India & & & 1 & 1.6 \\
\hline Latvia & & & 1 & 1.6 \\
\hline Sweden & & & 1 & 1.6 \\
\hline The Netherlands & & & 1 & 1.6 \\
\hline No information & & & 1 & 1.6 \\
\hline Total & & & 64 & 100.0 \\
\hline
\end{tabular}

Note. ${ }^{*}$ It is also named White Russia.

As the overwhelming majority of the Jewish communities were distributed among Western countries, so the JAE members came from a variety of Western states. As Table 9 shows, the largest group, 21 members, making up 32.8 percent of the JAE membership, was born in Tsarist Russia. Next to Tsarist Russia as a birth-place comes Poland, with twelve members, making up 18.7 percent, followed by Germany and the US with 6 members, or 9.4 percent, each. Of the American group, one was born in Maryland, and one in Ohio. New York State, owing to its sizable Jewish population, claimed four members. Rumania was a birth-place for five members and Britain for three.

In order to obtain a clearer view of the pattern of distribution of birth-places, the countries of birth are grouped into four regional groupings: Tsarist Russia and Eastern Europe, Central Europe, Western Europe and North America. As Table 10 shows, a little over two-thirds of the total Jewish elite group was born in Tsarist 
Russia and Eastern Europe. Next to this group come Central Europe and North America with seven members, or 10.9 percent, each. Western Europe had five members, or 7.8 percent; and India, the only non-Western country, with one member.

Table 10

A Breakdown of the Birth-Places of the Jewish Elite by Regional Grouping*

\begin{tabular}{lll}
\hline Regional grouping & No. & Percentage \\
\hline Tsarist Russia and Eastern Europe & 43 & 67.2 \\
Central Europe & 7 & 10.9 \\
North America & 7 & 10.9 \\
Western Europe & 5 & 7.8 \\
India & 1 & 1.6 \\
No information & 1 & 1.6 \\
Total & 64 & 100.0 \\
\hline
\end{tabular}

Notes. "Tsarist Russia and Eastern Europe grouping includes Byelorussia (White Russia), Ukraine, Russia, Poland, Rumania, Lithuania, Czechoslovakia, Hungary, Latvia. Central Europe includes Germany and Austria. Western Europe includes Britain, Sweden and the Netherlands. North America includes the US and Canada.

Comparing each region's percentage in the total birth-places of the elite group with its percentage in the total world Jewry, it becomes clear that Tsarist Russia and Eastern Europe, Central Europe, and Western Europe (even with the exclusion of the Jewish population of Sweden, on whose percentage in the total Jewish population information is not at hand) were overrepresented on the elite group, while North America was under-represented. While the Jewish population in Tsarist Russia and Eastern Europe made up 49 percent of world Jewry, this region served as a birth-place for 67.2 percent of the elite group. This percentage is likely to reflect the fact that this region was a major center of the Zionist activities, and that Jewish existence was experiencing living hardships in this region. And whereas the North American Jewish population in 1939 formed 30.4 percent of the world Jewish population, North American was the birth-place of only 10.9 percent of the elite group (see Table 11).

Table 11

A Breakdown of the Jewish Elite Group and of World Jewry by Regional Affiliation by Birth

\begin{tabular}{lll}
\hline Regional affiliation & \% of members & \% of world Jewry born there (in 1939) \\
\hline Tsarist Russia and Eastern & & \\
\hline Europe & 67.2 & 49.0 \\
Central Europe & 10.9 & 1.7 \\
North America & 10.9 & 30.4 \\
Western Europe & 7.8 & $3.2^{*}$ \\
India & 1.6 & \\
No information & 1.6 & \\
Total & 100.0 & \\
\hline
\end{tabular}

Notes. ${ }^{*}$ The percentage of the Jewish population in Sweden in the total world Jewry is not included here. Statistical information was extracted from The Palestine Year Book edited by Sophie A. Udin, op. cit., p. 77.

In the last two decades of the 19th century and during the first two decades of the 20th century, Europe was the major center of Zionist activity and hence the majority of the Zionist political elite group was recruited from the ideologically and politically socialized Zionist figures in Europe. Zionist socialization in Europe 
preceded that in North America. This partly explains the overrepresentation on the JAE of the European Jews, and the corresponding underrepresentation of the US and Canadian Jews. It should also be recalled that some JAE members whose birth-places were in Central Europe and Tsarist Russia emigrated to the US in childhood and were brought up in the US before they reached the elite ranks.

The countries in which the JAE members were born were the origin of diverse social and political ideologies. These countries were of various cultures. The populations of these countries approached the Jewish communities living among them with a variety of socially conditioned ways. This background is considerably accountable for the diversity of social, political and economic outlook to which members of the JAE were committed. In other words, the fact of the multitude of countries of birth for the JAE had divisive effects on it.

Available data reveal that out of the 64 members of the JAE, at least 61, representing 95.3 per cent, were born in towns and cities. This was because of the preponderant urban character of the Jewish communities (Patai, 1971, pp. 1163-1164).

\section{Ideology}

During the last one and a half centuries, political Jewish life has witnessed the formation of a number of political movements and institutions, the most influential of which is Zionism. Of the 64 JAE members, 57, making up 89 percent of the elite group, were Zionist, whereas seven members, making up 11 percent, were non-Zionist (see Table 11).

Zionism encompasses a number of ideas: socialism, liberalism, democracy, gathering of the Jews in Palestine, creating a Jewish state in it, revival of the Hebrew language and Hebrew-Jewish culture, and others. These ideas, within the framework of the Zionist movement, have been embodied in the political parties to which the JAE members belonged. These parties differed in their political, social and economic outlook and programs. In the following, a brief review of the parties' ideas is provided.

MAPAI (Mifleget Po'alei Eretz Yisrael) (The Party of the Workers of the Land of Israel) came into being as a result of the merger of Hapo'el Hatsa'ir (The Young Worker) and Achdut Ha'avoda (The Unity of Labor) in 1929. For MAPAI, Jewish nationalism meant a Jewish regeneration through Jewish conquest of Palestine by Jewish settlement and through social responsibility. It viewed Jewish public ownership of the land and of the means of production as a means to create a Jewish statehood. MAPAI identified the interests of the Zionist labor movement with the interests of the Jewish people.

Table 12

A Breakdown of the JAE by Ideological Affiliation

\begin{tabular}{lll}
\hline Ideological affiliation & No. & Percentage \\
\hline Zionists & 57 & 89 \\
Non-Zionists & 7 & 11 \\
Total & 64 & 100 \\
\hline
\end{tabular}

Socialism, Zionism and Jewish-Arab understanding formed the ideological platform of MAPAM (Mifleget Hapo’alim Hameduchedet) (The United Workers’ Party). Hapo'elha-Mizrachi (The Mizrachi Worker) was a Zionist religious labor party. Its approach to social, political and economic issues was derived from the Old Testament (Esco Foundation for Palestine, 1947, p. 957). Ichud Hatzionim Haklaliyim (Federation of the General Zionist) may be defined as a liberal party calling for profit-seeking free private enterprise (Esco 
Foundation for Palestine, 1947, p. 958). This multitude of partisan and ideological organizations was a reflection of the variety of countries and lands, with different regimes, to which the elite members were affiliated.

Ha'aliya Hachadasha (New Immigration) was a pro-British party which called for a business-like approach to the Palestine dispute (Esco Foundation for Palestine, 1947, p. 958). Mizrachi was a religious party which viewed Zionism as an offshoot of Judaism. It called for founding the Jewish state on the basis of the Old Testament (Esco Foundation for Palestine, 1947, p. 959). The Revisionists were a militant party which called for establishing a Jewish state on both sides of the Jordan River and for a firmer stand against both the Arabs and the British. They encouraged middle class colonization of Palestine and private initiative.

Ichud (Union) called for converting Palestine into a bi-national state where Arabs and Jews would have equal rights. Some Unionists advocated the neutralization of Palestine. Others advocated the inclusion of a bi-national Palestine in a Middle Eastern federation. The League for Jewish-Arab Rapprochement aimed at the same goals advocated by Union.

Table 13 states the partisan affiliation of the JAE members in 1948, the year in which the period coverage of the study stops, or in the year of the death of a member, if the death occurred before 1948. The Federation of General Zionists and MAPAI claimed 11 JAE members, making up 17.2 per cent, each. Seven, making up 10.9 percent, were identified with Mizrachi, whereas two members, making up 3.1 percent, belonged to the Mizrachi Worker. Union and the League for Arab-Jewish Rapprochement, MAPAM and the Revisionists claimed two members each. One member belonged to New Immigration. Nineteen members, making up 29.7 percent, were Zionists on whose partisan affiliation there was no information.

It would be revealing to compare the parties in terms of their attitudes towards the Arab-related questions. With respect to the bi-nationalism of the state of Palestine, the League for Arab-Jewish Rapprochement and Hashomer Hatza'ir (the Young Guard) — which was a wing of MAPAM-were the only two groups which advanced the idea. The rest of the Zionist JAE members insisted on the establishment of a Jewish state. With the exception of Union, all the Zionist members called for an increased and unlimited Jewish immigration in order to accelerate the process of creating a Jewish majority in Palestine. In contrast, Union called for immigration whereby a Jewish-Arab demographic parity could be brought about. Should the Jewish population be out-numbered by the Arab population, owing to the higher Arab demographic growth, a continuation of immigration to restore the demographic balance would be, for Union, dependent on an Arab-Jewish agreement.

Table 13

A Breakdown of the Jewish Elite Group by Partisan Affiliation

\begin{tabular}{lll}
\hline Partisan affiliation & No. & Percentage \\
\hline Federation of General Zionists & 11 & 17.2 \\
MAPAI & 11 & 17.2 \\
Mizrachi & 7 & 10.9 \\
Mizrachi Worker & 2 & 3.1 \\
Union and the League for Arab-Jewish & & \\
Rapprochement & 2 & 3.1 \\
MAPAM & 2 & 3.1 \\
Revisionists & 2 & 3.1 \\
'Aliya Hadasha (New Immigration) & 1 & 1.6 \\
Zionists whose partisan identity is not available & 19 & 29.7 \\
Non-Zionists & 7 & 10.9 \\
Total & 64 & 100.0 \\
\hline
\end{tabular}




\section{Political Opportunity}

The foregoing analysis can be a basis for identifying a number of prerequisite conditions for the admission of individuals to political elite status. Clearly, the number of persons entering for the first time the JAE depends on the frequency with which JAE membership vacancies occurred. Changes in the JAE composition were brought about either by members' assassination and death or by members' resignation due to disputes on political and ideological issues. Of course, this provided political opportunity for aspirants.

Another variable that affected the opportunity for individuals to enter the JAE was, naturally, its size. The larger is the JAE, the greater is the number of entrants to it. The size of the JAE had been constantly and appreciably fluctuating during the period under study. The 1921 JAE numbered fifteen. It numbered thirteen in 1923. In 1927 it reached an all-time low of nine members. The number again rose to thirteen in 1929. After fluctuations, the $1937 \mathrm{JAE}$ amounted to twenty members, and it rose to an all-time high of twenty-six members in 1939. The number then went down to twenty-one in the $1946 \mathrm{JAE}$.

Some other factors affected the political opportunity of ambitious persons. Political conditions often determined admissibility to the Jewish elite group. In the Jewish communities, as in other communities, political trustworthiness formed an important criterion for rise to political elite status. Political trustworthiness meant an earnest attachment to the Zionist and Jewish work and goals in Palestine.

Promotion to political prominence was also affected by economic factors. As made clear earlier in the article, the expansion of the Jewish Agency in 1929 to include non-Zionist Jews was motivated by financial considerations. The Zionist political elite calculated that by taking this step, wealthy American non-Zionists would make financial contributions to Jewish colonization of Palestine.

Political opportunity also depended on external factors. Non-Zionist Jews were representing Jewish communities in various Western countries, notably in Western Europe. Immediately after the expansion in 1929 of the Jewish Agency, Zionist and non-Zionist Jews were equally represented on the various organs of the JAE, the Council and the Administrative Committee of the Jewish Agency. But, mainly as a result of the Jewish holocaust in Central and Eastern Europe during World War II, the non-Zionist representation on the JAE was drastically reduced and it disappeared altogether in 1947.

Membership in the WZO was obtained by payment of a membership fee. Seats on the WZO's biennial Congress were allocated to Zionist individuals in various countries in proportion to the membership card holders in a country to the world total of membership card holders. The JAE, up to 1929, was elected by the Zionist Congress. After 1929, 50 percent of the JAE members were elected by the Zionist Congress. Consequently, the number and political orientation of the WZO card holders in the different countries had to do with the political opportunity open to political aspirants.

The JAE was elected biennially. Changes in the composition of the JAE, its size, and the regularity of its election were responsible for the not-too-small number of 64 elite group members who served as members of the JAE between 1921 and 1948.

The composition of the JAE was constantly changing. For example, five members who served on the 1921 15-person JAE made no appearance on the 1923 13-person one. With respect to the $1921 \mathrm{JAE}$, three new members were elected to the 1923 one. Nine persons who were members of the $1925 \mathrm{JAE}$ were not included in the 1927 one. Four members, who served on the 1933 JAE, were not re-elected to the 1935 one. Six individuals, with no former service on the $1935 \mathrm{JAE}$, were elected to the 1937 body. One 1937 JAE member made no 
re-appearance on the 1939 one, whereas seven individuals were elected to the 1939 JAE with no previous election to the $1937 \mathrm{JAE}$. Thirteen members, who were included in the $1939 \mathrm{JAE}$, made no reappearance in the 1946 one, which included seven new members, making up 33.3 percent. This constant change in the elite group composition attests to the invariable occurrence of vacancies in the JAE. No member served on all the JAEs.

In order to gain an insight into the extent of elite group circulation, the number of new JAE members was counted. Since the $1921 \mathrm{JAE}$ is viewed as the first one in this article, its 15 members were considered as new. As Table 14 indicates, there were new entrants with respect to every JAE. This indicates a continuous promotion of activists from the Jewish communities to elite status.

Table 14

A Breakdown of the Jewish Elite Group by New Admission of JAE Members by Each JAE

\begin{tabular}{llll}
\hline JAE & Total number of members & \multicolumn{2}{c}{ New members } \\
\hline 1921 & 15 & No. & $\%$ \\
\hline 1923 & 13 & 3 & 13.3 \\
1925 & 15 & 2 & 33.3 \\
1927 & 9 & 3 & 23.0 \\
1929 & 13 & 3 & 40.0 \\
1930 & 10 & 4 & 58.3 \\
1931 & 12 & 7 & 38.5 \\
1933 & 13 & 5 & 26.7 \\
1935 & 15 & 4 & 25.0 \\
1937 & 20 & 5 & 23.0 \\
1939 & 26 & 6 & 33.3 \\
1946 & 21 & 7 &
\end{tabular}

Besides, perhaps more meaningfully, the percentage of new persons in each JAE was relatively high. Their percentage in the $1925 \mathrm{JAE}$ stood at 13.3. With the exception of the 1925 body, no percentage of new recruits fell below 23. The percentages of new recruits in the 1930 and 1931 JAEs were particularly high. This is partially explainable by the inclusion of non-Zionist members in the JAE after the expansion of the Jewish Agency in 1929.

\section{Conclusion}

The case of the Jewish political elite corroborates the thesis that wide diversity of places of birth, residence, age, foreign travel, avenues to political power, regional affiliation, ideological identification, and political opportunity contributes to the creation of various socio-political and economic views and that the location of such places has a say in determining the style of the elite's political action.

\section{References}

Cohen, I. (1950). Contemporary Jewry: A survey of social, cultural, economic and political conditions. London: Methuen.

Esco Foundation for Palestine. (1947). Palestine: A study of Jewish, Arab and British policies. New Haven, CT: Yale University Press.

Khouri, F. J. (1971). The Arab-Israeli dilemma. Syracuse, NY: Syracuse University Press.

Lenczowski, G. (Ed.). (1975). Political elites in the Middle East. Washington, DC: American Enterprise Institute for Public Policy Research.

Patai, R. (Ed.). (1971). Encyclopedia of Zionism and Israel. New York: Herzl Press.

Udin, S. A. (Ed.). (1948). The Palestine year book and Israeli annual, 1947-48 (Vol. III). New York: Zionist Organization of 
America.

Weinrich, A. K. H. (1971). Chiefs and councils in Rhodesia. London: Heinemann.

Weinrich, A. K. H. (1973). Black and White elites in rural Rhodesia. Manchester: Manchester University Press. 